\title{
Incidência de Isquemia Miocárdica no Pós-Operatório de Pacientes Submetidos à Cirurgia para Correção de Aneurisma de Aorta Abdominal. Estudo Retrospectivo *
}

\section{Postoperative Myocardial Ischemia in Patients Undergoing Abdominal Aortic Aneurysm Repair. A Retrospective Study}

\author{
Domingos Dias Cicarelli, TSA ${ }^{1}$, Cristina Keiko Marumo ${ }^{2}$, Ricardo Gonçalves Esteves ${ }^{2}$
}

\begin{abstract}
RESUMO
Cicarelli DD, Marumo CK, Esteves RG - Incidência de Isquemia Miocárdica no Pós-Operatório de Pacientes Submetidos à Cirurgia para Correção de Aneurisma de Aorta Abdominal. Estudo Retrospectivo
\end{abstract}

Justificativa e Objetivos - Muitos pacientes submetidos à cirurgia para correção de aneurisma de aorta abdominal apresentam doença coronariana, podendo evoluir com complicações cardíacas perioperatórias. A grande dificuldade é avaliar, no pré-operatório, o risco de complicações cardíacas isquêmicas que ocorrem no período pós-operatório de modo confiável. O objetivo deste estudo foi verificar a incidência de isquemia cardíaca pós-operatória em pacientes submetidos à correção de aneurisma da aorta abdominal, sua correlação com o índice de risco cardíaco de Goldman modificado, com alterações no teste do tálio-dipiridamol e os fatores de risco nessa população.

Método - Foram analisados retrospectivamente 65 pacientes submetidos à correção de aneurisma da aorta abdominal e a incidência dos fatores de risco como tabagismo, insuficiência coronariana, hipertensão arterial sistêmica e Diabetes mellitus. Foi analisada a correlação entre a insuficiência coronariana no pré-operatório, o índice de Goldman modificado e as complicações isquêmicas pós-operatórias. Foi avaliada a correlação do teste tálio-dipiridamol pré-operatório e eventos isquêmicos no pós-operatório.

Resultados - Cerca de $80 \%$ dos pacientes apresentavam antecedente de tabagismo, $55 \%$ de hipertensão arterial, $8 \%$ de Diabetes mellitus, $25 \%$ de insuficiência coronariana. Entre os pacientes com insuficiência coronariana, cinco possuíam angina pré-operatória e apresentaram uma incidência de $40 \%$ de isquemia miocárdica no pós-operatório, sendo a incidência de infarto agudo do miocárdio de 6,2\%. No nosso estudo, $14 \%$ dos pacientes Goldman modificado II e $33 \%$ dos pacientes Goldman modificado III apresentaram isquemia miocárdica pós-operatória. Dezesseis pacientes (24\%) foram submetidos ao tálio dipiridamol no pré-operatório, sendo que 10 (62\%) apresentaram defeitos de captação cintilográfica. O valor preditivo positivo do exame foi de $20 \%$ para isquemia

\footnotetext{
* Recebido do (Received from) CET/SBA da Disciplina de Anestesiologia do Hospital de Clínicas da Faculdade de Medicina da Universidade de São Paulo

1. Co-responsável pelo CET/SBA

2. $M E_{2}$ do CET/SBA
}

Apresentado (Submitted) em 08 de novembro de de 2000

Aceito (Accepted) para publicação 28 de dezembro de 2000

Correspondência para (Mail to)

Dr. Domingos Dias Cicarelli

Av. Piassanguaba, 2933/71 - Planalto Paulista

04060-004 São Paulo, SP

(C) Sociedade Brasileira de Anestesiologia, 2001 miocárdica pós-operatória, com valor preditivo negativo de $83 \%$ e sensibilidade de $66 \%$.

Conclusões - A incidência de complicações cardíacas de acordo com o índice de Goldman modificado não foi compatível com o risco teórico desse índice. Os pacientes com angina no período pré-operatório apresentaram alta porcentagem (40\%) de isquemia no pós-operatório, sendo que o valor do tálio-dipiridamol como teste preditivo de complicações isquêmicas foi baixo.

UNITERMOS: CIRURGIA, Vascular; COMPLICAÇÕES: insuficiência coronariana

\section{SUMMARY}

Cicarelli DD, Marumo CK, Esteves RG - Postoperative Myocardial Ischemia in Patients Undergoing Abdominal Aortic Aneurysm Repair. A Retrospective Study

Background and Objectives - Many patients undergoing abdominal aortic aneurysm repair are at high risk for perioperative myocardial ischemia. The great difficulty is to reliably evaluate the preoperative risk of postoperative myocardial ischemia. This study aimed at observing the incidence of postoperative myocardial ischemia in patients submitted to abdominal aortic aneurysm repair, its correlation with Goldman's modified cardiac risk index, with changes in the dipyridamole-thallium test and the risk factors for such population.

Methods - Participated in this retrospective study 65 patients submitted to abdominal aortic aneurysm repair. Risk factors, such as smoking, coronary artery disease, systemic hypertension and diabetes mellitus, were evaluated as well as the correlation among preoperative coronary artery disease, Goldman's modified cardiac index risk and postoperative myocardial ischemia. The correlation between preoperative dipyridamolethallium test and postoperative cardiac complications was also evaluated.

Results - Approximately $80 \%$ of patients were smokers, $55 \%$ were hypertensive, $8 \%$ had diabetes mellitus and $25 \%$ of patients presented with coronary artery disease. Among coronary artery disease patients, five patients had preoperative angina with an incidence of $40 \%$ of postoperative myocardial ischemia and $6.2 \%$ of myocardial infarction. In our study, $14 \%$ of Goldman's modified II and 33\% of Goldman's modified III had postoperative myocardial ischemia. Sixteen patients (24\%) were submitted to preoperative dipyridamole- thallium test and 10 patients (62\%) presented reperfusion defects. Positive dipyridamole- thallium test predictive value was $20 \%$ for postoperative myocardial ischemia with a negative predictive value of $83 \%$ and sensitivity of $66 \%$.

Conclusions - The incidence of cardiac complications as predicted by Goldman's modified index was not compatible with the theoretical risk of such index. Patients with preoperative angina had a high percentage (40\%) of postoperative ischemia and dypiramidole-thalium test had a low ischemia-predicting value. KEY WORDS - COMPLICATIONS: myocardial ischemia; SURGERY, Vascular 


\section{INTRODUÇÃO}

A incidência de isquemia miocárdica em pacientes submetidos à correção de aneurisma de aorta abdominal está em torno de $6 \%{ }^{1}$. Nas duas últimas décadas, esta incidência vem diminuindo pela evolução do tratamento para insuficiência coronariana (revascularização do miocárdio, terapia trombolítica, angioplastia). No entanto, a busca por um método de avaliação pré-operatória com alto valor preditivo para isquemia miocárdica perioperatória continua. Avaliações de risco cardíaco, como o índice de Goldman ${ }^{2}$, têm validade para grandes populações submetidas a cirurgias não cardíacas, porém tal validade não se mantém para populações submetidas a grandes cirurgias vasculares. Detsky e col. ${ }^{3}$ modificaram tais índices, aumentando seu valor preditivo.

Múltiplos testes têm sido utilizados para avaliar a presença e a extensão da doença arterial coronariana. Os exames de cintilografia com tálio-dipiridamol e ecocardiograma de estresse com dobutamina têm sido preconizados para pacientes incapacitados para o exercício, particularmente aqueles submetidos a grandes cirurgias vasculares ${ }^{4}$. O tálio-dipiridamol como teste de rastreamento tem sido questionado, apresentando valor preditivo significativo apenas para pacientes com risco moderado ( 1 ou 2 fatores de risco) pela avaliação clínica ${ }^{5}$.

O objetivo deste estudo é verificar a incidência de isquemia miocárdica em pacientes submetidos à correção de aneurisma de aorta abdominal e analisar a correlação entre as complicações isquêmicas pós-operatórias e os fatores de risco, índice de risco cardíaco de Goldman modificado e alterações de reperfusão no teste do tálio-dipiridamol.

\section{MÉTODO}

Após aprovação pela Comissão de Ética em Pesquisa desta Instituição, foram estudados pacientes submetidos à correção de aneurisma de aorta abdominal eletivamente, cujos pós-operatórios foram acompanhados na Unidade de Apoio Cirúrgico do Centro Cirúrgico do Hospital de Clínicas da FMUSP de janeiro de 1998 a dezembro de 1999. O estudo foi retrospectivo.

Foram coletados os seguintes dados dos prontuários dos pacientes: idade, sexo, peso, medicamentos em uso, co-morbidades como hipertensão arterial sistêmica, Diabetes mellitus, doença pulmonar obstrutiva crônica, acidente vascular cerebral prévio, doença arterial coronariana (infarto do miocárdio, revascularização do miocárdio, angioplastia, angina), alterações eletrocardiográficas (sobrecarga ventricular esquerda, ondas $Q$, bloqueios) e no teste de tálio-dipiridamol (hipocaptação persistente ou transitória).

Os pacientes foram classificados segundo o critério de risco cardíaco de Goldman modificado. De acordo com a classificação de cada paciente, este índice prediz o risco de complicações cardíacas, conforme a tabela I.
Tabela I - Percentagem de Complicações Cardíacas de Acordo com o Risco Cardíaco de Goldman Modificado

\begin{tabular}{lc}
\hline Classe & Complicações Cardíacas (\%) \\
\hline I & 1 \\
II & 7 \\
III & 14 \\
IV & 78 \\
\hline
\end{tabular}

Foi verificada a presença de isquemia miocárdica e os critérios para diagnóstico de infarto do miocárdio utilizados foram $^{6}$ :

- Alteração eletrocardiográfica a partir do ECG pré-operatório: supradesnivelamento do segmento ST de pelo menos $2 \mathrm{~mm}$ em 2 derivações consecutivas ou aparecimento de bloqueio de ramo inexistente na avaliação pré-operatória;

- Quadro clínico de precordialgia ou dor atípica sem outra causa;

- Elevação de enzimas cardíacas - CKMB correspondendo a $5 \%$ da CPK total ${ }^{7}$.

O diagnóstico de infarto do miocárdio foi baseado na presença de pelo menos dois desses critérios. Os óbitos por infarto do miocárdio foram confirmados por necrópsia.

A associação entre os fatores de risco presentes na população estudada e as complicações isquêmicas pós-operatórias foi analisada através do teste do Qui-Quadrado com correção de Yates e o nível de significância considerado foi $p<$ 0,05 .

Em relação ao teste de tálio-dipiridamol foram analisados os valores preditivos positivo e negativo, sensibilidade e especificidade.

\section{RESULTADOS}

Foram estudados 65 pacientes submetidos à correção de aneurisma de aorta abdominal ( 53 infra-renais e 12 justa-renais). Os pacientes apresentavam idades entre 53 e 77 anos $(67,9 \pm 6,27)$, sendo 50 do sexo masculino e 15 do sexo feminino $(77 \% / 23 \%)$. Aincidência dos fatores de risco na população estudada encontra-se na tabela II.

Nenhum dos fatores de risco estudados apresentou associação estatisticamente significante com as complicações isquêmicas pós-operatórias. Dos cinco pacientes com quadro de angina pré-operatória sem tratamento invasivo prévio (revascularização ou angioplastia), dois apresentaram isquemia (40\%).

Seis pacientes $(9,23 \%)$ apresentaram evento isquêmico pós-operatório: duas isquemias, quatro infartos agudos do miocárdio (IAM) $(6,15 \%)$, sendo que destes, três foram a óbito. Dos 65 pacientes, 31 foram considerados Goldman I e não apresentaram complicação, 28 foram considerados Goldman II e apresentaram quatro complicações isquêmicas $(14 \%)$ e seis foram classificados como Goldman III e apresentaram duas complicações isquêmicas (33\%). 
Tabela II - Incidência dos Fatores de Risco na População Estudada

\begin{tabular}{llc}
\hline Fator de risco & $\mathrm{n}^{\circ}$ & Porcentagem \\
\hline Tabagismo & 52 & 80 \\
Hipertensão arterial & 36 & 55 \\
Isuficiência coronariana & 16 & 25 \\
Obstrução arterial crônica & 7 & 11 \\
Obstrução carótida & 6 & 9 \\
Etilismo & 5 & 8 \\
Diabetes mellitus & 5 & 8 \\
Insuficiência cardiaca congestiva & 4 & 6 \\
Valvuloplastia & 2 & 3 \\
\hline
\end{tabular}

A relação entre as alterações eletrocardiográficas pré-operatórias (bloqueios, áreas inativas e sobrecarga ventricular esquerda) e as complicações isquêmicas não foi estatisticamente significante.

Apenas 16 pacientes apresentavam o teste de tálio-dipiridamol no pré-operatório. Destes, 11 apresentavam algum tipo de alteração na captação cintilográfica (8 com hipocaptação persistente e 3 com hipocaptação transitória).

O valor preditivo positivo do exame foi $20 \%$, o valor preditivo negativo foi $83 \%$ e a sensibilidade $66 \%$.

\section{DISCUSSÃO}

Aincidência de isquemia miocárdica foi de $9,23 \%$ na população estudada. Em 1995, Fleisher e col. ${ }^{1}$ encontraram uma incidência de $6 \%$ para eventos isquêmicos em pacientes submetidos à cirurgia de aorta, enquanto Baron e col. ${ }^{8}$, em 1994, encontraram uma incidência de $18 \%$ em 457 pacientes submetidos ao mesmo tipo de cirurgia. Neste mesmo trabalho, concluiu-se que evidência clínica de doença arterial coronariana e idade maior que 65 anos foram os fatores de risco de maior valor preditivo para eventos cardíacos adversos no pós-operatório deste tipo de cirurgia. Em nosso estudo, não conseguimos comprovar tal fato.

De acordo com Fleisher e col. ${ }^{4}$, a presença de insuficiência cardíaca congestiva (ICC) está associada com alto risco perioperatório. Em nosso estudo, 50\% dos pacientes com ICC foram a óbito. Este dado é compatível com a literatura, levando-se em consideração que todos os pacientes neste estudo apresentavam ICC por causa isquêmica, o que caracteriza maior risco perioperatório. Pelo mesmo estudo, Fleisher e col. verificaram alta relação de Diabetes mellitus com morbidade cardíaca perioperatória. Em nosso estudo, a prevalência de Diabetes mellitus ( $8 \%$ ) foi baixa e não conseguimos comprovar tal relação. O fator de risco mais prevalente em nossa população foi o tabagismo (80\%), sendo até maior que a hipertensão arterial (55\%).

Mangano e col. ${ }^{9}$ encontraram $41 \%$ de isquemia miocárdica pós-operatória em pacientes com doença arterial coronariana ou com alto risco para insuficiência coronariana submetidos a cirurgia eletiva não cardíaca. Tal incidência é compatí- vel com o nosso achado de $40 \%$ de eventos isquêmicos em pacientes coronariopatas sem tratamento invasivo prévio.

Analisamos, ainda, o real valor preditivo da classificação de Goldman (risco cardíaco) em nossos pacientes. Utilizamos a classificação de Goldman modificada por Detsky, por esta apresentar melhor correlação com o aparecimento de complicações pós-operatórias. Mesmo assim, o risco teórico pelo Goldman modificado subestimou o risco real destes pacientes. Em nosso estudo, os pacientes Goldman II e III apresentaram duas vezes mais complicações do que o risco teórico. Dessa forma, notamos que os fatores levados em conta na classificação de Goldman modificada ainda são poucos e não avaliam de forma precisa o estado clínico do paciente ${ }^{10}$.

Sabe-se que os pacientes submetidos a cirurgias vasculares apresentam grande risco para doença coronariana. No entanto, a maioria se apresenta incapacitada para o exercício físico. A partir desse fato, métodos farmacológicos foram desenvolvidos para simular os efeitos fisiológicos do exercício, como o teste do tálio-dipiridamol. Estudos anteriores mostravam alto valor preditivo $(30-50 \%)$ do tálio com alteração da redistribuição ${ }^{11}$ para infarto agudo do miocárdio pós-operatório. Em 1991, Mangano e col. ${ }^{12}$ demonstraram, através de estudo prospectivo, que não havia associação entre defeitos de reperfusão e isquemia perioperatória, sendo o valor preditivo positivo do exame de $27 \%$. Sugeriram que os resultados adversos após a cirurgia, particularmente o infarto agudo do miocárdio, foram devidos a várias causas, como aumento da demanda de oxigênio do miocárdio, trombose e outras etiologias, não testadas especificamente pelo teste do tálio-dipiridamol. Em 1994, Baron e col. ${ }^{8}$, através de estudo prospectivo com 457 pacientes submetidos à cirurgia de correção de aorta abdominal, confirmaram que não existe associação e o valor preditivo do tálio foi de 19\%. O valor preditivo positivo do tálio encontrado em nosso estudo é compatível com esse resultado. Deste modo, o tálio não é indicado rotineiramente para todos os pacientes que serão submetidos a grandes cirurgias vasculares.

Eagle e col. ${ }^{5}$, em 1989, delinearam um grupo de variáveis clínicas (ondas Q, história de ectopia ventricular, Diabetes mellitus, idade avançada e angina) e demonstraram que, subgrupos sem nenhum fator de risco ou com múltiplos fatores de risco, os eventos adversos seriam claramente preditos pelos marcadores clínicos, de modo que a cintilografia não forneceria informação adicional. No entanto, um exame de tálio com alteração de reperfusão seria útil em pacientes considerados de risco moderado (1 ou 2 fatores de risco). A cintilografia com defeito fixo representa morbidade para alguns autores ${ }^{13,14}$. A redistribuição de tálio sugere que algumas dessas áreas de defeitos fixos podem representar grave isquemia com grande risco de necrose miocárdica durante o estresse cirúrgico.

Em nosso estudo, todos os pacientes com tálio pré-operatório apresentavam um ou dois fatores de risco. Considerando defeitos de reperfusão e fixos, o tálio-dipiridamol apresentou valor preditivo positivo de $20 \%$, valor preditivo negativo de $83 \%$, sensibilidade de $66 \%$ e especificidade de $38,5 \%$. 
A hipertrofia de ventrículo esquerdo e a depressão de segmento ST vistos no eletrocardiograma pré-operatório são fatores de risco importantes para infarto agudo do miocárdio e morte de causa cardíaca após grandes cirurgias vasculares ${ }^{15}$. Não encontramos risco aumentado de IAM pós-operatório para alterações eletrocardiográficas pré-existentes analisadas neste estudo, da mesma forma como foi descrito por Sprung e col. ${ }^{16}$.

Concluindo, verificamos que a incidência de isquemia miocárdica pós-operatória é alta (40\%) entre pacientes coronariopatas com manifestação clínica (angina). O índice de Goldman modificado subestimou o risco de complicações isquêmicas em pacientes submetidos à correção eletiva de aneurisma de aorta abdominal. Entre os fatores de risco analisados, não verificamos correlação com eventos cardíacos pós-operatórios, provavelmente pelo tamanho da população estudada. O valor preditivo positivo do tálio-dipiridamol para complicações isquêmicas pós-operatórias foi baixo ${ }^{17}$.

\section{Postoperative Myocardial Ischemia in Patients Undergoing Abdominal Aortic Aneurysm Repair. A Retrospective Study}

Domingos Dias Cicarelli, M.D., Cristina Keiko Marumo, M.D., Ricardo Gonçalves Esteves, M.D.

\section{INTRODUCTION}

The incidence of myocardial ischemia in patients submitted to abdominal aorta aneurysm repair is approximately $5 \%{ }^{1}$. Such incidence is decreasing during the last two decades due to coronary failure treatment evolution (myocardial revascularization, thrombolytic therapy, angioplasty). However, the search for a preoperative evaluation method with a high predictive value for perioperative myocardial ischemia is still ongoing. Cardiac risk evaluations, such as Goldman's index ${ }^{2}$, are valid for large populations submitted to non-cardiac surgeries, but do not work for populations submitted to major vascular surgeries. Destky et al. ${ }^{3}$ have modified such index, thus increasing its predictive value.

Several tests have been used to evaluate the presence and extension of coronary artery disease. Dypiramidole-thalium scintigraphy and stress echocardiogram with dobutamine have been recommended for patients unable to exercise especially those submitted to major vascular surgeries ${ }^{4}$. Dypiramidole-thalium screening test has been questioned and has a significant predictive value only for patients at moderate risk (1 or 2 risk factors) ${ }^{5}$.

This study aimed at evaluating the incidence of myocardial ischemia in patients submitted to abdominal aorta aneurysm repair and the correlation between postoperative ischemic complications and risk factors, Goldman's modified cardiac risk index and reperfusion changes in the dypiramidolethalium imaging.

\section{METHODS}

After the institution's Research Ethics Committee approval, participated in this retrospective study patients submitted to elective abdominal aorta aneurysm repair, the postoperative period of whom was followed at the Surgical Support Unit of the Surgical Center, Hospital das Clinicas FMUSP, from January 1998 to December 1999. The following data were gathered from patients' records: age, gender, weight, prescribed drugs, co-morbidities, such as systemic hypertension, diabetes mellitus, chronic obstructive pulmonary disease, previous stroke, coronary artery disease (myocardial infarction, myocardial revascularization, angioplasty, angina), ECG changes (left ventricular overload, Q waves, blockades), dypiramidole-thalium imaging changes (persistent or transient under-intake). Patients were classified according to Goldman's modified cardiac risk index. According to each patient's classification, such index predicts cardiac complications risks, as shown in table I.

Table I - Cardiac Complications According to Goldman's Modified Cardiac Risk (\%)

\begin{tabular}{lc}
\hline Class & Cardiac Complications (\%) \\
\hline I & 1 \\
II & 7 \\
III & 14 \\
IV & 78 \\
\hline
\end{tabular}

The presence of myocardial ischemia was evaluated and criteria for myocardial infarction diagnostic were ${ }^{6}$ :

- Electrocardiographic changes as from preoperative ECG: supra-unleveling of ST segment of at least 2 $\mathrm{mm}$ in 2 consecutive leads or the blockade of a branch not seen during preoperative evaluation;

- Clinical precordialgia or atypical pain of unknown etiology;

- Heart enzymes increase - CKMB corresponding to $5 \%$ of total $\mathrm{CPK}^{7}$.

Myocardial infarction diagnosis was based on the presence of at least two criteria. Myocardial infarction deaths were confirmed by necropsy.

The association between risk factors and postoperative ischemic complications was analyzed by the chi-square test with Yates correction considering significant $p<0.05$.

Positive and negative predictive values, sensitivity and specificity were evaluated for dypiramidole-thalium imaging.

\section{RESULTS}

Participated in this study 65 patients submitted to abdominal aorta aneurysm repair ( 53 infra-renal and 12 juxta-renal). Patients aged 53 to 77 years $(67.9 \pm 6.27), 50$ were males and 15 females $(77 \% / 23 \%)$. Table II shows the incidence of risk factors in this population. 
Table II - Incidence of Risk Factors in our Sample

\begin{tabular}{lcc}
\hline Risk Factor & $\mathrm{n}^{\circ}$ & Percentage \\
\hline Smoking & 52 & 80 \\
Hypertension & 36 & 55 \\
Coronoray failure & 16 & 25 \\
Chronic arterial obstruction & 7 & 11 \\
Carotid obstruction & 6 & 9 \\
Alcoholism & 5 & 8 \\
Diabetes mellitus & 5 & 8 \\
Congestive heart failure & 4 & 6 \\
Valvuloplasty & 2 & 3 \\
\hline
\end{tabular}

No risk factor presented a statistically significant association with postoperative ischemic complications. From the five patients with preoperative angina without previous invasive treatment (revascularization or angioplasty), two presented with ischemia $(40 \%)$.

Six patients $(9.23 \%)$ had postoperative ischemic events: 2 ischemias and 4 myocardial infarctions (MI) (6.15\%) and three evolved to death.

Of the 65 patients, 31 were considered Goldman I and had no complications, 28 were considered Goldman II and had four ischemic complications (14\%) and 6 were considered Goldman III with two ischemic complications (33\%).

The relationship between preoperative ECG alterations (blockades, inactive areas and left ventricular overload) and ischemic complications was not statistically significant.

Only 16 patients were submitted to preoperative dypiradamole-thalium imaging. Of those, 11 had some type of scintigraphy uptake changes ( 8 with persistent and 3 with transient under-intake).

Test's positive predictive value was $20 \%$, negative predictive value was $83 \%$ and sensitivity was $66 \%$.

\section{DISCUSSION}

The incidence of myocardial ischemia was $9.23 \%$ in our sample. In 1995, Fleisher et al. ${ }^{1}$ have found a $6 \%$ incidence of ischemic events in patients submitted to aorta surgeries, while Baron et al. ${ }^{8}$, in 1994, reported an incidence of $18 \%$ in 457 patients submitted to the same surgery. This same study concluded that clinical evidence of coronary disease and more than 65 years of age were the risk factors with the highest predictive value for postoperative adverse cardiac events in this type of surgery. Our study was unable to show such risk.

According to Fleisher et al. ${ }^{4}$, congestive heart failure (CHF) is associated to high perioperative risk. In our study, $50 \%$ of $\mathrm{CHF}$ patients died. This is in line with the literature, taking into consideration that all studied patients had ischemic CHF, which characterizes a higher perioperative risk. In the same study, Fleisher et al. have observed a high correlation between diabetes mellitus and perioperative cardiac morbidity. In our study, diabetes mellitus incidence was low (8\%) and such relationship was not shown. Most prevalent risk factor in our sample was smoking (80\%), being even higher than hypertension (55\%).

Mangano et al. ${ }^{9}$ have found $41 \%$ of postoperative myocardial ischemia in patients with coronary disease or at high risk for coronary failure submitted to elective non-cardiac surgeries. Such incidence is compatible with our findings of $40 \%$ of ischemic events in coronary disease patients without previous invasive treatment.

The real predictive value of Goldman's classification (cardiac risk) was also evaluated in our patients. We decided for Goldman's classification modified by Detsky for having a better correlation with postoperative complications. Even then, Goldman's modified theoretical risk has underestimated the actual risk of such patients. In our study, Goldman I and II patients presented two times more complications than the theoretical risk, So, we observed that the factors taken into account in Goldman's modified classification are few and do not accurately evaluate patients' clinical status ${ }^{10}$.

It is known that patients submitted to vascular surgeries are at high risk for coronary diseases. However, most are unable to exercise and pharmacological methods have been developed to simulate physiological exercise effects, such as dypiridamole-thallium imaging. Previous studies have shown a high predictive value for thallium (30-50\%) with redistribution changes ${ }^{11}$ for postoperative myocardial infarction. In 1991, Mangano et al. ${ }^{12}$ have shown in a prospective study that there was no association between reperfusion defects and perioperative ischemia, with a positive predictive value of $27 \%$. They suggested that postoperative adverse effects, especially myocardial infarction, were due to different causes, such as an increase in myocardial oxygen demand, thrombosis and other etiologies, not specifically tested by dypiramidole-thalium imaging. In 1994, Baron et al. ${ }^{8}$ in a prospective study with 457 patients submitted to abdominal aorta repair confirmed that there is no association and that thalium's predictive value was $19 \%$. Thalium's positive predictive value in our study is compatible with this result. So thalium is not routinely indicated for all patients to be submitted to major vascular surgeries.

Eagle et al. ${ }^{5}$, in 1989 , established a set of clinical variables (Q waves, ventricular ectopia history, diabetes mellitus, older age and angina) and have shown that in sub-groups with no risk factor or with multiple risk factors adverse events would be clearly predicted by clinical markers, and that scintigraphy would not bring additional information. However, a thallium test with reperfusion changes would be useful for moderate risk patients ( 1 or 2 risk factors). Scintigraphy with fixed defect represents morbidity for some authors ${ }^{13,14}$. Thallium redistribution suggests that some fixed defect areas may represent severe ischemia with a high risk for myocardial necrosis during surgical stress.

In our study, all patients with preoperative thallium presented one or two risk factors. Considering reperfusion and fixed defects, dypiramidole-thallium had a positive predictive value of $20 \%$, a negative predictive value of $83 \%$, a sensitivity of $83 \%$ and a specificity of $38.5 \%$. 
Left ventricular hypertrophy and ST segment depression at preoperative ECG are important risk factors for myocardial infarction and cardiac death after major vascular surgeries ${ }^{15}$. In our study, we have not found increased postoperative MI risk for preexisting ECG alterations evaluated, similar to what has been described by Sprung et al. ${ }^{16}$.

To conclude, we have observed that the incidence of postoperative myocardial ischemia is high $(40 \%)$ among cardiac patients with clinical manifestations (angina). Goldman's modified index has underestimated the risk for ischemic complications in patients submitted to abdominal aorta aneurysm repair. Among the risk factors evaluated, we have not seen correlation with postoperative cardiac events, probably due to the sample size. Positive dipyridamole-thallium predictive value for postoperative ischemic complications was low ${ }^{17}$.

\section{REFERÊNCIAS - REFERENCES}

01. Fleisher LA, Rosenbaum SH, Nelson AH et al - Preoperative dipyridamole thallium imaging and ambulatory electrocardiographic monitoring as a predictor of perioperative cardiac events and long term outcome. Anesthesiology, 1995;83: 906-917.

02. Goldman L, Caldera DL, Nussbaum SR et al - Multifactorial index of cardiac risk in noncardiac surgical procedures. N Engl J Med, 1977; 297:845-850

03. Detsky A, Abrams H, McLaughlin J et al - Predicting cardiac complications in patients undergoing noncardiac surgery. J Gen Intern Med, 1986;1:211-219.

04. Fleisher LA - Preoperative assessment of the patient with cardiovascular disease. Anais da Jornada Paulista de Anestesiologia, 1999;33:15-19.

05. Eagle KA, Coley CM, Newell JB et al - Combining clinical and thallium optimizes preoperative assessment of cardiac risk before major vascular surgery. Ann Intern Med, 1989;110:859- 866.

06 . Executive summary of the ACC/AHA task force report: guidelines for perioperative cardiovascular evaluation for noncardiac surgery. Anesth Analg, 1996;82:854-860.

07. Edwards ND, Reilly CS - Detection of perioperative myocardial ischemia. Br J Anaesth, 1994;72:104-115.

08. Baron JF, Mundler O, Bertrand M et al - Dipyridamole - thallium scintigraphy and gated radionuclide angiography to assess cardiac risk before abdominal aortic surgery. N Engl J Med, 1994; 330:663-669.

09. Mangano DT, Browner WS, Hollenberg M et al - Association of perioperative myocardial ischemia with cardiac morbidity and mortality in men undergoing noncardiac surgery. N Engl J Med, 1990;323:1781-1788.

10. Fleisher LA - Perioperative management of the cardiac patient undergoing noncardiac surgery. Annual Refresher Course Lectures - ASA, 1995;23:221.

11. Boucher CA, Brewster DC, Darling RC et al - Determination of cardiac risk by dipyridamole thallium imaging before peripheral vascular surgery. N Engl J Med, 1985;312:389-394.

12. Mangano DT, London MJ, Tubau JF et al - Dipyridamole thallium - 201 scintigraphy as a preoperative screening test: A re-examination of its predictive potential. Circulation, 1991;84:493-502.

13. McEnroe CS, O'Donnel T, Yeager A et al - Comparison of ejection fraction and Goldman risk factor analysis to dipyridamolethallium 201 studies in the evaluation of cardiac morbidity after aortic aneurysm surgery. J Vasc Surg, 1990;11:497-504.
14. Marwick TH, Underwood DA - Dipyridamole thallium imaging may not be a reliable screening test for coronary artery disease in patients undergoing vascular surgery. Clin Cardiol, 1990;13: 14-18.

15. Landesberg G, Einav S, Christopherson R et al - Perioperative ischemia and cardiac complications in major vascular surgery: Importance of the preoperative twelve lead electrocardiogram. J Vasc Surg, 1997;26:570-578.

16. Sprung J, Abdelmalak B, Gottlieb A et al - Analysis of risk factors for myocardial infarction and cardiac mortality after major vascular surgery. Anesthesiology, 2000;93:129-140.

17. Fleisher LA, Nelson AH, Rosenbaum SH - Failure of negative dipyridamole thallium scans to predict perioperative myocardial ischaemia and infarction. Can J Anaesth, 1992;39:179-183.

\section{RESUMEN}

Cicarelli DD, Marumo CK, Esteves RG - Incidencia de Isquemia Miocárdica en el Pós-Operatorio de Pacientes Sometidos a Cirugía para Corrección de Aneurisma de Aorta Abdominal. Estudio Retrospectivo

Justificativa y Objetivos - Muchos pacientes sometidos a cirugía para corrección de aneurisma de aorta abdominal presentan enfermedad coronariana, pudiendo evolucionar con complicaciones cardíacas perioperatorias. La gran dificultad es evaluar, en el pré-operatorio, el riesgo de complicaciones cardíacas isquémicas que ocurren en el período pósoperatorio de modo confiable. El objetivo de este estudio fue verificar la incidencia de isquemia cardíaca pós-operatoria en pacientes sometidos a corrección de aneurisma de la aorta abdominal, su correlación con el índice de riesgo cardíaco de Goldman modificado, con alteraciones en el test del tálio-dipiridamol y los factores de riesgo en esa población.

Método - Fueron analizados retrospectivamente 65 pacientes sometidos a corrección de aneurisma de la aorta abdominal y la incidencia de los factores de riesgo como tabagismo, insuficiencia coronariana, hipertensión arterial sistémica y Diabetes mellitus. Fue analizada la correlación entre la insuficiencia coronariana en el pré-operatorio, el índice de Goldman modificado y las complicaciones isquémicas pós-operatorias. Fue evaluada la correlación del test tálio-dipiridamol pré-operatorio y eventos isquémicos en el pós-operatorio.

Resultados - Cerca de $80 \%$ de los pacientes presentaban antecedente de tabagismo, 55\% de hipertensión arterial, $8 \%$ de Diabetes mellitus, $25 \%$ de insuficiencia coronariana. Entre los pacientes con insuficiencia coronariana, cinco tenian angina pré-operatoria y presentaron una incidencia de $40 \%$ de isquemia miocárdica en el pós-operatório, siendo la incidencia de infarto agudo del miocárdio de 6,2\%. En nuestro estudio, $14 \%$ de los pacientes Goldman modificado II e 33\% de los pacientes Goldman modificado III presentaron isquemia miocárdica pós-operatoria. Dieciséis pacientes (24\%) fueron sometidos al tálio-dipiridamol en el pré-operatorio, siendo que $10(62 \%)$ presentaban defectos de captación cintilográfica. El valor preditivo positivo del examen fue de $20 \%$ para isquemia miocárdica pós-operatoria, con valor preditivo negativo de $83 \%$ y sensibilidad de $66 \%$.

Conclusiones - La incidencia de complicaciones cardíacas de acuerdo con el índice de Goldman modificado no fue compatible con el riesgo teórico de ese índice. Los pacientes con angina en el período pré-operatorio presentaron alta porcentaje (40\%) de isquemia en el pós-operatorio, siendo que el valor del tálio-dipiridamol como test preditivo de complicaciones isquémicas fue bajo. 